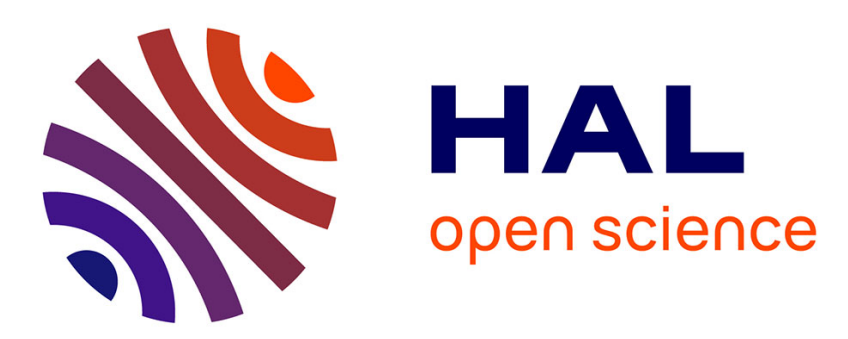

\title{
Seasonal variability of the backscattering coefficient in the Mediterranean Sea based on Satellite SeaWiFS imagery
}

\author{
Hubert Loisel, E Bosc, D Stramski, K Oubelkheir, Py Deschamps
}

\section{To cite this version:}

Hubert Loisel, E Bosc, D Stramski, K Oubelkheir, Py Deschamps. Seasonal variability of the backscattering coefficient in the Mediterranean Sea based on Satellite SeaWiFS imagery. Geophysical Research Letters, 2001, 28 (22), pp.4203-4206. 10.1029/2001GL013863 . hal-03483042

\author{
HAL Id: hal-03483042 \\ https://hal.science/hal-03483042
}

Submitted on 28 Dec 2021

HAL is a multi-disciplinary open access archive for the deposit and dissemination of scientific research documents, whether they are published or not. The documents may come from teaching and research institutions in France or abroad, or from public or private research centers.
L'archive ouverte pluridisciplinaire HAL, est destinée au dépôt et à la diffusion de documents scientifiques de niveau recherche, publiés ou non, émanant des établissements d'enseignement et de recherche français ou étrangers, des laboratoires publics ou privés. 


\title{
Seasonal variability of the backscattering coefficient in the Mediterranean Sea based on Satellite SeaWiFS imagery
}

\author{
H. Loisel, ${ }^{1}$ E. Bosc, ${ }^{2}$ D. Stramski, ${ }^{3}$ K. Oubelkheir, ${ }^{2}$ and P.-Y. Deschamps ${ }^{1}$
}

\begin{abstract}
The annual progression of the particulate backscattering coefficient, $b_{\text {bp, }}$ within the whole Mediterranean sea is examined from satellite remote sensing and inverse modeling for the first time. This study reveals that $b_{\text {tp }}$ is roughly distributed uniformly over the Mediterranean that differs from the well known east-west gradient in terms of chlorophyll concentration, $C h l$. In contrast to $C h l, b_{\mathrm{bp}}$ is also weakly variable along the seasons, and presents different extrema. These observations are attributed to the presence of high concentrations of submicrometer particles such as detrital particles, heterotrophic bacteria and also possibly mineral particles from aeolian inputs. The interpretation of $b_{\mathrm{bp}}$ in terms of particulate organic carbon concentration, $P O C$, is discussed, and a relationship between $b_{b p}$ and $P O C$ is developed. Application of our algorithm to SeaWiFS data indicates that the satellite estimates are in good agreement with surface $P O C$ measurements.
\end{abstract}

\section{Introduction}

The inherent optical properties (IOP) of seawater depend on the type and the concentration of the various constituents in presence. Besides the water itself, the dissolved and particulate substances determine the IOP. Among these IOP, the backscattering coefficient, $b_{\mathrm{b}}$, is not sensitive to the dissolved material, and can be used as an index of the particulate load. As an IOP, the backscattering coefficient can be partitioned according to:

$$
b_{\mathrm{b}}(\lambda)=b_{\mathrm{bw}}(\lambda)+b_{\mathrm{bp}}(\lambda)
$$

where $\lambda$ is the wavelength of light, $b_{b w}(\lambda)$ is a constant representing the backscattering of the pure seawater, and $b_{\mathrm{tp}}(\lambda)$ the backscattering coefficient by particles suspended in seawater. For simplicity the argument $\lambda$ will be omitted, unless specifically required. The $b_{\mathrm{bp}}$ variability is determined by changes in the concentration and composition of the particulate assemblage that mostly consists of particulate organic carbon $(P O C)$ within the open ocean. Biogenic $\mathrm{CaCO}_{3}$ particles often encountered during coccolithophore blooms, and mineral particles from aeolian inputs may also contribute episodically to $b_{\mathrm{tp}}$ in open ocean waters [Gordon et al., 2001; Guerzoni et al., 1999]. The recent capability to

\footnotetext{
'Laboratoire d'Optique Atmosphérique, Université des Sciences et Technologies de Lille, Villeneuve d'Ascq, France

${ }^{2}$ Laboratoire d'Oceanographie de Villefranche, Villefranche-sur-mer, France

${ }^{3}$ Scripps Institution of Oceanography, University of California San

Diego, La Jolla, California

Copyright 2001 by the American Geophysical Union.
}

Paper number 2001GL013863.

0094-8276/01/2001GL013863\$05.00 retrieve $b_{\mathrm{hp}}$ from space observation of ocean color [Carder et al., 1999; Loisel and Stramski, 2000] provides the opportunity to investigate the spatial and temporal variability of $P O C$ that is an important factor in determining the ocean's role in the global balance of carbon [Eppley and Peterson, 1979]. In contrast to the chlorophyll concentration, $C h l$, which is the index usually adopted to specify the bio-optical state of a water body, the seasonal variations and the spatial distribution of $P O C$ remain poorly known and mostly restricted to ship observations. Until now, only one study was conducted at large scale from ocean color data collected by the Seaviewing Wide Field-of-view Sensor (SeaWiFS) [Stramski et al., 1999]. This study revealed the seasonal progression of $P O C$ all around Antarctica that is a very specific environment due to particular phytoplankton assemblages encountered in these high-latitude waters [Mitchell and Holm-hansen, 1991].

The objective of this study is to describe the seasonal variations of $b_{\mathrm{bp}}$ from space observation of ocean color within the entire Mediterranean. The patterns of the remotely sensed $b_{\text {tp }}$ will be compared to those of the remotely sensed $C h l$, in order to determine whether $b_{\mathrm{bp}}$ provides additional information about the biogeochemical features of the Mediterranean. The interpretation of $b_{\mathrm{bp}}$ in terms of $P O C$, and the comparison with in situ $P O C$ measurements will be discussed. The choice of the Mediterranean is motivated by two main raisons. First, although the Mediterranean represents only $0.8 \%$ of the world ocean area, it shows strong trophic variability: from ultra oligotrophic waters during summer in the eastern basin, to eutrophic conditions associated with the spring bloom in some areas of the western basin. In this respect, the Mediterranean sea acts as a miniature ocean for biogeochemical studies. Second, the Mediterranean is characterized by relatively low cloud coverage that allows its frequent observation from space.

\section{Method}

Monthly data of the SeaWiFS-derived remote sensing spectral reflectance, $R_{\mathrm{rs}}(\lambda)$, were acquired from the Nasa Goddard Distributed Active Archive Center for the years 1998 and 1999. The SeaWiFS-Chl is derived from $R_{\mathrm{rs}}(\lambda)$ according to the current SeaDAS processing code [O'Reilly et al., 1998]. The retrieval of $b_{\mathrm{tp}}$ at $\lambda=555 \mathrm{~nm}$ from $R_{\mathrm{rs}}(\lambda)$ is based on the model recently developed by Loisel and Stramski [2000] and successfully tested against in situ measurements performed in offshore and coastal environments [Loisel et al., 2001]. This model accounts for Raman scattering that can significantly affect $R_{\mathrm{rs}}(\lambda)$ in oligotrophic waters, and shows relatively little sensitivity to changes in the scattering phase function, and to the vertical structure of the IOP profiles. In the context of remote sensing application, assuming that the error on the retrieval of $R_{\mathrm{rs}}(\lambda)$ is small, the relative difference between the modeled and measured $b_{\mathrm{tp}}$ never exceeds $30 \%$, and the average value of this difference is $17 \%$ [Loisel et al., 2001]. 

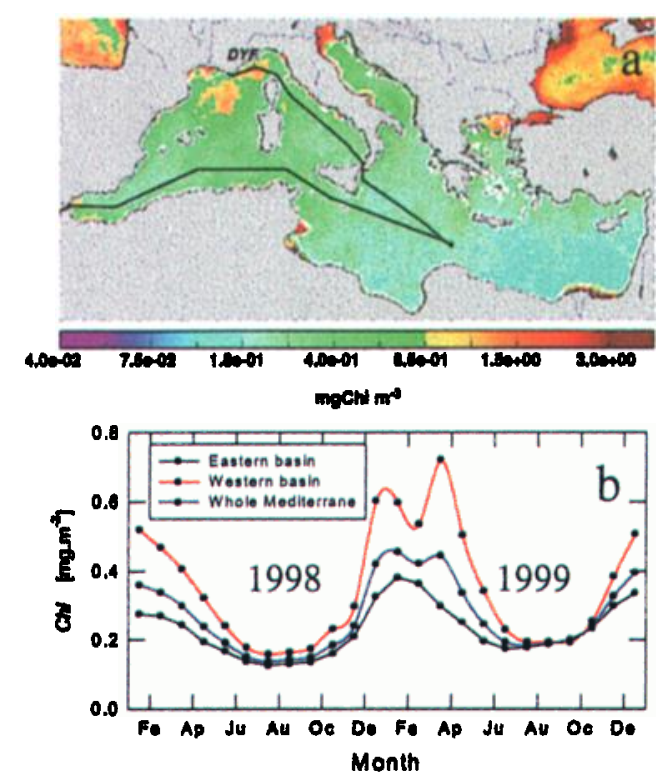

Figure 1. (a) Chl distribution for the Mediterranean sea in March 1998. The location of the DyFAMed site $(D Y F)$ and the PROSOPE cruise track are superimposed on this composite SeaWiFS image. (b) The seasonal progression of $\mathrm{Chl}$ within the western, the eastern and the whole Mediterranean for the year 1998 and 1999. The eastem and westem basins are separated by the Strait of Sicily.

Monthly values of $b_{b \mathrm{p}}$ and $C h l$ were derived by summing the products $X_{\mathrm{i}}, S_{\mathrm{i}}$ (where $X_{\mathrm{i}}$ is the value of $C h l$ or $b_{\mathrm{bp}}$ at the pixel $\mathrm{i}$, and $S_{\mathrm{i}}$ is the area of this pixel) and then dividing the result by the total area of the region. We will present only the results for the western and the eastern basins, and for the whole Mediterranean. For the interpretation of particular patterns, however, we also made similar calculations over 10 different subregions as defined by Guerzoni et al. [1999]. Turbid waters were excluded from these calculations according to the criteria adopted by Bricaud and Morel [1987].

\section{Results}

Because the seasonal and spatial $\mathrm{Chl}$ features of the Mediterranean were already studied in details by many authors [Antoine et al., 1995 and references therein], we only briefly remind the main patterns. For this purpose, the Chl distribution within the whole Mediterranean in March 1998 is shown in Figure la, and the monthly variations of $\mathrm{Chl}$ averaged over the western and eastern basins, and over the whole Mediterranean, are plotted in Figure $1 \mathrm{~b}$ for the years 1998 and 1999. As seen, the Mediterranean is characterized by a permanent trophic gradient from the western to the eastern basin, with the lowest $C h l$ values always confined in the south part of the eastern basin (Figure 1). The maximum $C h l$ values are observed within the Adriatic sea in winter, and in the northwestern Mediterranean during the spring bloom period. Note that if the 1998 spring bloom does not appear on the mean spatial $\mathrm{Chl}$ value (but does exist as seen in Figure 1a), the very broad and intense 1999 bloom clearly affects the $\mathrm{Chl}$ value averaged over the western basin (Figure 1b). With regards to the seasonal $C h l$ variations, they are generally more pronounced in the western basin than in the eastern basin, and the difference between the two basins vanishes in summer when $C h l$ reaches its minimum value (Figure $1 \mathrm{~b}$ ).

In a similar way the distribution of $b_{\mathrm{tp}}$ within the whole Mediterranean in March 1998, and its annual course for each basin are plotted in Figure 2. Unfortunately, no in situ backscattering data are available for the Mediterranean to verify the consistency of our values. This is due to the lack of optical instrumentation that allows to estimate $b_{\mathrm{bp}}$ from in situ measurements, until recently. Nevertheless, the retrieved $b_{b p}$ values present the same order of magnitude as those recently measured in other similar oceanic areas [Loisel et al., 2001; Stramska et al., 2000], and are also consistent with recent in situ measurements performed in the Adriatic sea (J.-F. Berthon, personal communication). Similarly to $C h l$, the highest $b_{\mathrm{bp}}$ values are noticed along the coasts, in front of the river mouths, and in the western Mediterranean during the spring phytoplankton bloom period (Figure 2a). Nevertheless, the comparison of Figures 1 and 2 also highlights some remarkable differences between the $C h l$ and $b_{b p}$ patterns, regarding both their spatial and temporal variability. First, the permanent $\mathrm{Chl}$ gradient between the relatively rich western basin and the relatively poor eastern basin is not always associated with a similar $b_{\mathrm{bp}}$ gradient. The west-east contrast is much less pronounced for $b_{\mathrm{bp}}$ and can also be slightly reverse from July to December 1999, as clearly seen in Figure $2 b$. In a similar way, the north-south dissymetry in the eastern basin is much less noticeable in terms of $b_{\mathrm{bp}}$ than in terms of $C h l$ (Figure 2a). Thus, as a general statement, $b_{\mathrm{bp}}$ appears to be more homogeneously distributed within the Mediterranean than $C h l$. Second, in contrast to $C h l, b_{\mathrm{tp}}$ is weakly variable along the seasons. For example, the ratio of the maximum over the minimum value of $\mathrm{Chl}$ within the western (eastern) is 3.8 (2.6) compared to $1.74(1.6)$ for $b_{\mathrm{bp}}$ in 1998. Finally, the extremes values of $b_{\mathrm{tp}}$ do not always match those of $\mathrm{Chl}$. For example, while $C h l$ is minimum in July, $b_{b p}$ reaches his minimum value 3 months later. Moreover, besides the maximum in March 1998 and 1999 owing to the northwestern bloom, $b_{\mathrm{bp}}$ also exhibits a distinct maximum in May 1998 or in July 1999 within the two basins. This second maximum in
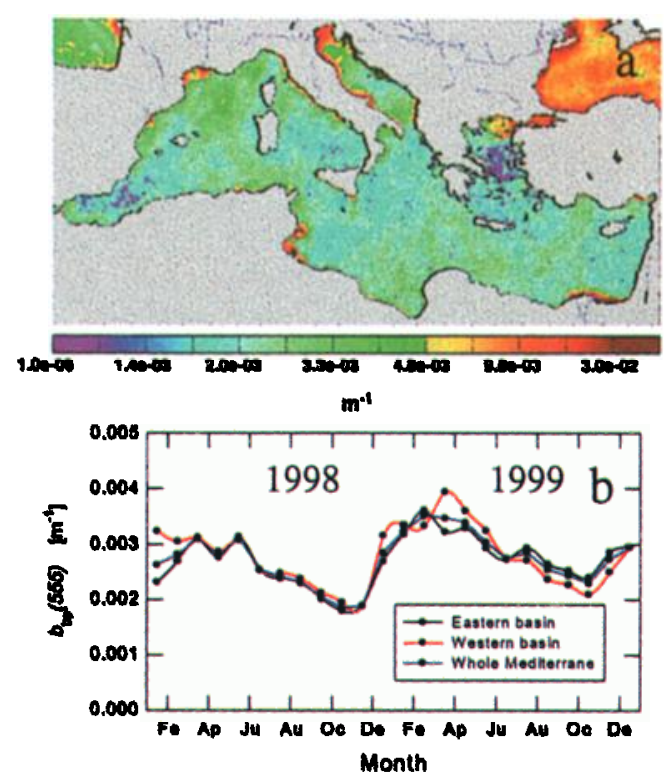

Figure 2. As in figure 1 but for $b_{\mathrm{bp}}$. 


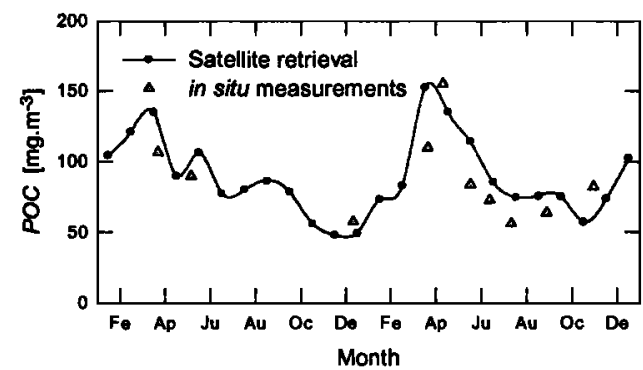

Figure 3. Comparison of the measured (triangles) and retrieved (line and dotes) POC concentration for the years 1998 and 1999 at the DyFAMed site.

May or in July does not correspond to any enhancement of Chl even if one consider each subregions of the Mediterranean as defined above (the same remark holds for the eastern basin in March 1998).

\section{Discussion}

The bulk backscattering depends on both the concentration of particles and the single-particle cross section (the product of the geometrical cross section by the efficiency factor which is a function of the size and of the refractive index). Based upon Mie-scattering calculations Stramski and Kiefer [1991] and Morel and Ahn, [1991] demonstrated that most of the backscattering (70-90\%) in oceanic waters is caused by particles smaller than $1 \mu \mathrm{m}$. Among these particles, small $(<0.6 \mu \mathrm{m})$, non-living (detrital) suspended particles are believed to be the major source of backscattering as they occur in sufficiently high concentrations to dominate $b_{\mathrm{bp}}$ in oceanic waters [Ulloa et al., 1994 and references therein]. This is consistent with in situ observations that showed that non-living submicronic particles occur at a concentration at least one order of magnitude higher than living particles in surface ocean [Koike et al.,1990]. Heterotrophic bacteria are the second major backscatters in the ocean, and account typically for 5 to $20 \%$ of backscattering in oligotrophic waters depending on their concentration [Stramski and Kiefer, 1991]. Finally, the contribution of algae cells to $b_{\mathrm{bp}}$ is negligible as a result of their weak backscattering efficiency. Nevertheless, under bloom conditions the photoautotrophic picoplankters can contribute significantly to $b_{\mathrm{bp}}$ as clearly seen in March 1999 (Figure 2b). Therefore, the seasonal and spatial differences between the $C h l$ and $b_{\mathrm{bp}}$ patterns are primarily caused by the fact that most of the backscatters in oceanic waters are nonalgal particles such as biogenic detritus, and heterotrophic organisms. For example, the weak $b_{\mathrm{bp}}$ longitudinal gradient, that can not be explained by episodic events, suggests an almost uniform spatial distribution of submicrometer particles (living and non-living) within the whole basin. While photoautotrophic picoplankters and especially their associated material may be the major contributors to $b_{\mathrm{bp}}$ within the western basin, the great abundance of submicrometer particles typical to an "old" system of production based on the microbial loop, may be responsible of the backscattering process within the eastern basin. This is consistent with the results of Dolan et al. [1999] that suggest a shift from the western to the eastern basins in the planktonic food web towards a microbially dominated system.
Submicron Saharan dust in suspension within the upper layer may also contribute, after an aeolian deposition event, to the enhancement of $b_{\mathrm{bp}}$ (due to their high refractive index). For example, the maximum in March 1998 within the eastern Mediterranean was attributed to the high $b_{\mathrm{bp}}$ values observed within the Levantin basin where no enhancement of $C h l$ was noticed. During the second half of March, several Saharan dust events were recorded by the TOMS sensor (and also by SeaWiFS) over the Levantin basin, that could explain these high $b_{b p}$ values. Note that such event does not introduce an artificial bias within the monthly composite of $R_{\mathrm{rs}}$. We verified that the value of $R_{\mathrm{rs}}$ at $410 \mathrm{~nm}$ (where a bad correction of the aerosol contribution would have the maximum effect) is not correlated with the aerosol optical thickness, $\tau_{\mathrm{a}}$, and does not present any depletion when $\tau_{\mathrm{a}}$ is maximal. Some Saharan dust events have also been recorded in May 1998 and July 1999 that could explain the high $b_{\mathrm{bp}}$ values observed during these months. The maxima observed in May 1998 and in July 1999 within the western basin could also be explained by the presence of organic detritus generated in condition of post bloom (the few months shift between 1998 and 1999 can be attributed to the great intensity of the 1999 spring bloom that lasts longer than that in 1998).

\section{Application: estimation of $P O C$ from $b_{\mathrm{bp}}$}

It is now believed that the dominant contribution to particle organic carbon in the ocean is of submicrometer particles [Melnikov, 1976; Koike et al., 1990; Longhurst et al., 1992]. The presence of these submicrometer particles that are in sufficient high concentration to dominate $b_{\mathrm{tp}}$ in oceanic waters suggest that $b_{\mathrm{bo}}$ and $P O C$, are well correlated. This was confirmed by recent in situ measurements of $b_{\mathrm{bp}}$ that led to an almost linear relationship between $b_{\mathrm{bp}}$ and $P O C$ within the Southern ocean [Stramski et al., 1999]. Because no in situ b bp data are available for the Mediterranean, the relationship between $b_{\mathrm{bp}}$ and $P O C$ is established in two steps: first, the dependence of the scattering coefficient by particles, $b_{\mathrm{p}}(555)$, on the $P O C$ concentration is analyzed from data collected within the Mediterranean, and second, the relation between $b_{\mathrm{bp}}(555)$ and $b_{\mathrm{p}}(555)$ is developed from the SeaBASS data set. During the PROSOPE cruise conducted within the Mediterranean (see tracks in Figure 1) in late summer 1999, simultaneous determination of $b_{\mathrm{p}}(555)$ and $P O C$ led to a highly correlated relationship: $P O C=453 b_{\mathrm{p}}(555)+1.3\left(\mathrm{r}^{2}=\right.$ 0.85 ) [Oubelkheir et al., submitted]. This relation is similar to that previously established in the north western Mediterranean in December 1998-January 1999 [Claustre et al., 2000]. Analysis of recent in situ measurements of $b_{\mathrm{p}}$ and $b_{\mathrm{bp}}$ made simultaneously in open ocean, and gathered within the SeaBASS data base, aims at fixing the backscattering ratio $\left(b_{\mathrm{bp}} / b_{\mathrm{p}}\right)$ at $0.012\left(\mathrm{r}^{2}=0.84\right.$; even if $b_{\mathrm{bp}} / b_{\mathrm{p}}$ can covary with $C h l$, we have adopted a constant value at a first approximation). For this analysis, only data with similar $C h l$ and $b_{\mathrm{p}}$ ranges as observed in Mediterranean were used. This value is consistent with the backscattering ratio based on Petzold's measurements $(=0.019)$, which is commonly assumed to represent "average" ratio for marine particles [Mobley et al. 1993]. By combining the relation of $P O C$ versus $b_{\mathrm{p}}(555)$ and $b_{\mathrm{p}}(555)$ versus $b_{\mathrm{tp}}(555)$ we then obtain: $P O C=37750$ $b_{\mathrm{bp}}(555)+1.3$. This relationship allows us to estimate $P O C$ within the Mediterranean for the first time. 
This approach is tested through a comparison of the retrieved and measured $P O C$ at the French-JGOFS time serie DyFAMed site (see Figure 1a), where regular measurements of $P O C$ are performed. These measurements were not included in the set of data used in the development of the relationship between $b_{\mathrm{p}}$ and $P O C$. Figure 3 compares the monthly estimated $P O C$ concentration, with the daily measured $P O C$ surface values at the site Dyfamed. As seen, the seasonal progression of $P O C$, which is only dependant on the seasonal progression of $b_{\mathrm{tp}}$, is well reproduced. This point is a good indication of the linearity between $b_{\mathrm{bp}}$ and $P O C$. The mean ratio of the satellite-to-in situ POC values is $1.13 \pm 0.24$ $(\mathrm{N}=10)$. The relatively good agreement between the measured and retrieved $P O C$ concentration is surprising according to the different possible sources of errors involving in this comparison. It should be noted, however, that no attempt has been made to tune the algorithm to the measurements.

\section{Concluding remarks}

This approach can directly be applied over the global ocean to analyze the spatial distribution and the seasonal variations of the particulate matter stock (through the spatial and temporal variations of $b_{\mathrm{bp}}$ ). The estimation of $P O C$ concentration, however, requires future in situ investigations in various oceanic areas in order to derive regional parameterizations of the $P O C-b_{\mathrm{bp}}$ relationship. Such investigations will also give access to the $P O C / C h l$ ratio from remote sensing, which is related to the relative carbon mass of autotrophs and heterotrophs.

Acknowledgments. We thank $H$. Claustre and A. Bricaud for discussions and comments on the manuscript. We also thank P. Raimbault and N. Garcia for the $P O C$ analysis performed during the PROSOPE cruise, and I. Vescovali for the $P O C$ measurements at the DYFAMED site. This is a contribution of the PROSOPE group (PROOF-JGOFS-France). In situ $b_{\mathrm{p}}$ and $b_{\mathrm{bp}}$ measurements gathered within the SeaBASS data base (years 1998 and 1999) were obtained in the frame of the SIMBIOS project. This work was supported by Centre National d'Études Spatiales.

\section{References}

Antoine, D., A; Morel, and J-M. André, Algal pigment distribution and primary production in the eastern Mediterranean as derived from coastal zone color scanner observations, J. Geophys. Res., 100, 16,193-16,209, 1995.

Bricaud, A. and A. Morel, Atmospheric correction and interpretation of marine radiances in CZCS imagery: Use of a reflectance model, Oceanol. Acta. Spec. Pbubl. 33-50, 1987.

Carder, K. L. et al. , Semianalytic moderate-resolution imaging spectrometer algorithms for chlorophyll a and absorption with biooptical domains based on nitrate-depletion temperatures, $J$. Geophys. Res., 104, 5403-5421, 1999.

Claustre, $\mathrm{H}$. et al., Continous monitoring of surface optical properties across a geostrophic front: biogeochemical inferences. Limnol. Oceanogr. 45(2), 309-321, 2000.
Dolan, J. R., F. Vidussi, H. Claustre, Planktonic ciliates in the Mediterranean sea: longitudinal trends, Deep-Sea Res., 46, 20252039, 1999.

Eppley, R. W., and B. J. Peterson, particulate organic matter flux and planktonic new production in the deep ocean, Nature, 282, 677$680,1988$.

Gordon, H. et al., Retrieval of coccolithophore calcite concentration from seaWiFS Imagery, Geophys. Research Letter, 28, 1587$1590,2001$.

Guerzoni, S. et al., The role of atmospheric deposition in the biogeochemistry of the Mediterranean Sea, Prog. Oceano. 44, 147-190, 1999.

Koike, I. et al., Role of sub-micrometer particles in the ocean, Nature, 345, 242-243, 1990.

Loisel H. and D. Stramski, Estimation of the inherent optical properties of natural waters from irradiance attenuation coefficient and reflectance in the presence of Raman scattering, Appl. Opt. 39, 3001-3011, 2000.

Loisel H. et al., Comparison of the ocean inherent optical properties obtained from measurements and inverse modeling, Appl. Opt. 40, 2384-2397, 2001.

Longhurst, A. R., et al., Submicron particles in northwest Atlantic shelf water, Deep-Sea Res., 39, 1-7, 1992.

Melnikov, I. A., Microplankton and organic detritus in the southeastern Pacific, Oceanology, 15, 103-110, 1976.

Mitchell, B., G. and O. Holm-hansen, Bio-optical properties of Antarctic Peninsula waters: differentiation from temperate ocean models, Deep-Sea Res., 38, 1009-1028, 1991.

Morel, A. and Y-H. Ahn, Optics of heterotrophic nanoflagellates and ciliates: A tentative assessment of their scattering role in oceanic waters compared to those of bacterial and algal cells, $J$. Marine Res., 48, 1-26, 1991.

Mobley, C. D. et. al., Comparison of numerical models for computing under-water light fields, Appl. Opt. 32, 7484-7504, 1993.

Oubelkheir, K. et al., The comparative bio-optical and biogeochemical properties of different trophic regimes, Limnol and Oceanogr, submitted.

O'Reilly, J. E. et al., Ocean color chlorophyll algorithms for seaWiFS, J. Geophys. Res., 103, 24937-24953, 1998.

Sramska, M. et al., Estimation of the absorption and backscattering coefficients from in-water radiometric measurements, Limnol. Oceanogr., 45, 628-641, 2000.

Stramski D. and D. A. Kiefer, Light scattering by microorganisms in the open ocean, Prog. Oceanogr., 28, 343-383, 1991.

Stramski D. et al., Estimation of particulate organic carbon in the ocean from satellite remote sensing, Science, 285, 239-242, 1999.

Ulloa, O., S. Sathyendranath, and T. Platt, Effect of the particle-size distribution on the backscattering ratio in seawater, Appl. Opt., 33, 7070-7077, 1994.

H. Loisel and P.-Y. Deschamps, Laboratoire d'Optique Atmosphérique, Université des Sciences et Technologies de Lille, 59655 Villeneuve d'Ascq, France (e-mail: pyd@loa.univ-lille1.fr; loisel@loa.univ-lille1.fr)

E. Bosc and K. Oubelkheir, Laboratoire d'océanographie de Villefranche, 06238 Villefranche-sur-mer, France (e-mail: bosc@obs-vlfr.fr, kadija@obs-vlfr.fr)

D. Stramski, Scripps Institution of oceanography, University of california San Diego, La Jolla, California 92037 (e-mail: stramsi@ucsd.edu)

(Received July 30; accepted August 17, 2001) 